\title{
Using 5-(4-aminoantipyrineazo)-8-hyrroxyquinoline as Complexometry Reagent with Cupper (II) and Zinc (II) Ions and its Biological Activity
}

\author{
Asaad A. Ali, Tark A. Fahad and Wesam A. Abdullah
}

Chemistry Department, Education College for Pure Science, Basrah University, Basrah, Iraq

E-mail-drasaad111@yahoo.com,drtarek_58@yahoo.com,Wseam2013@yahoo.com

\section{Abstract}

The complexes of azo dye 5-(4-aminoantipyrineazo)-8-hyroxyquinoline (L) with cupper (II) and zinc (II) lons were synthesized. Characterization of these azo dyes complexes have been done on the basis of elemental analysis and IR techniques. The work involves a study of optimum conditions (time, $\mathrm{pH}$, sequence of addition and temperature effects) for forming the complexes. The spectra of the complexes have been studied for a range of concentrations which Lambert Beer's law were obeyed with sensitivity of the spectrophotometric method in terms of molar absorptivity $1.6 \times 10^{4}$ and $1.2 \times 10^{4} \mathrm{I} . \mathrm{mol}^{-1} . \mathrm{cm}^{-1}$ for zinc and cupper azo dyes complexes respectively. The stoichiometry of the complexes has been found to be 1:2 (metal : ligand). The overall stability constants were determined by the corresponding solutions method. The interferences effects of the foreign ions were studied. The biological activity of two complexes with two type of Bacteria (Clostridium botulinum and Escherichia Coli) were also studied.

Keywords: Azo dye complexes; Solvent effects; Stability constant; Biological activity

\section{Council for Innovative Research}

Peer Review Research Publishing System

Journal: Journal of Advances in Chemistry

Vol. 11, No. 1

editorjaconline@gmail.com 


\section{Introduction}

Azo compounds are a very important class of chemical compounds receiving attention in scientific research. They are highly colored and have been used as dyes and pigments for a long time. Furthermore, they have been studied widely because of their excellent thermal and optical properties in applications [1]. Azo derivatives complex combinations have been widely used as dyes for synthetic polyamide supports and as pigments [2]. Azo derivatives and their metal complexes are very important pigments for synthetic leather and vinyl polymers and used as analytical reagent of many metals ions [3]. On the other hand, azo compounds are known to be involved in a number of biological reactions, such as inhibition of DNA, RNA, and protein synthesis, nitrogen fixation [4,5]. Furthermore metal-azo complex dyes are used in the recording layer of DVD-R ( Digital Versatile Disc-Recordable) discs . In comparison with the dyes themselves, metalazo dyes are more light stable, allow for easier control of the wavelength by selection of the appropriate substituent groups and have good thermal stability [6,7]. The systematic name of 4-aminoantipyrine is 4-amino-2,3-dimethyl-1-phenyl-3pyrazolin-5-one or 4-amino-phenazone which is widely used in medicine and pharmaceutical fields [8]. The antimicrobial activity of the 4-aminoantipyrine and its complexes $\left(\mathrm{Cu}^{2+}\right.$ and $\left.\mathrm{Zn}^{2+}\right)$ have been extensively studied on microorganisms such as Staphylococcus aureus, Klebsiela pneumonia, Bacillus subtillis, Escherichia coli, Citrobacter ferundii and Salmonella typhi, most of the complexes have higher activities than that of the free ligand [9] . The azo dyes compounds have been used as antiseptic and antibiotic [10] and also used as drugs, like 3-phenylazopyridine-2,6-diyldiamine[ 11] and salicylic azo sulfopyridine [12]. The sulfa azo dyes derived from 1-hydroxy-2-naphthoic acid were prepared as antibiotic and complexing reagents [13,14]. A azo compound, 8-quinolinol-5-azoantipyrine, was studied as an inhibitor for the corrosion of mild steel in $1 \mathrm{M} \mathrm{HCl}$ [15]. The 7-arylazo-8-hydroxyquinoline is a good reagent for forming a stable complexes with dioxouranium (VI) [ 16] and $\mathrm{Cu}(\mathrm{II})$ [17] . Zinc (II) ions were determined spectrophotometrically with 7-(4Nitro phenylazo )-8-hydroxyquinoline-5-sulfonic acid )[18] .

The present work involves the use of azo dye 5-(4-aminoantipyrineazo)-8-hyroxyquinoline ( which was prepared previously in part I (Scheme 1 )) [19] for the formation of complexes with cupper (II) and zinc (II) ions under optimum conditions (time, $\mathrm{pH}$, sequence of addition and temperature effects ). Study the ability of these complexes as biological reagents for two types of Bacteria ( Clostridium botulinum and Escherichia Coli).

\section{Experimental}

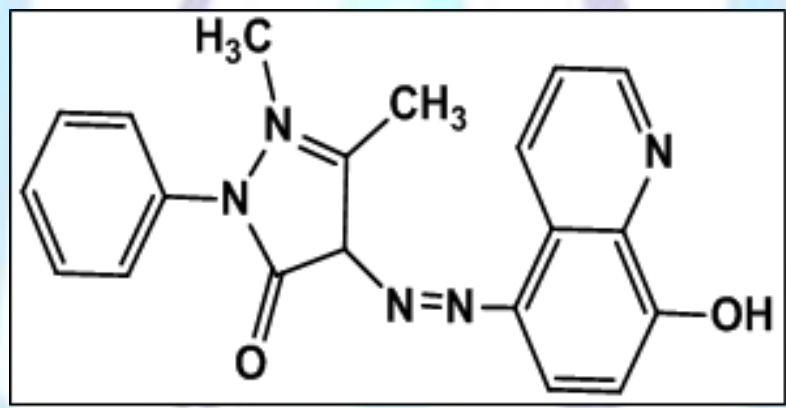

Scheme 1

Double distilled water and all the reagents and solvents were of reagent-grad quality, The progress of reaction was monitored by TLC using silica gel coated plate sand spots were visualized under UV radiation. Infrared spectra (in $\mathrm{K} \mathrm{Br}$ pellets) were recorded on IR-8400S shimadzu, Melting points were determined on melting point apparatus, Element analysis (C.H.N.) were carried out by Perkin element 2400 clement analysis and UV/V is absorption spectra studies of the dyes were recorded using Perkin Elmer Lampda EZ 210 UV/V Spectrophotometer. The pH measurements were made with $\mathrm{pH}-$ Meter $(\mathrm{H}$. Jurgons Co. Bremen,L. Puls Munchen15). The $\mathrm{Cu}(\mathrm{II})$ and $\mathrm{Zn}(\mathrm{II})$ ions were determined by atomic absorption spectrophotometer U.K., Pg. instruments AA500

\section{Solutions}

- A stock solution of $\left(1 \times 10^{-3} \mathrm{M}\right)$ of azo dye $\mathrm{L}$ were prepared by dissolving an accurately weighed amount of the compounds in the ethanol and more dilute solution were obtained by accurate dilution.

- A stock solution of $\left(1 \times 10^{-3} \mathrm{M}\right)$ of each $\mathrm{Cu}\left(\mathrm{NO}_{3}\right)_{2} .3 \mathrm{H}_{2} \mathrm{O}$ and $\mathrm{Zn}\left(\mathrm{NO}_{3}\right)_{2} .6 \mathrm{H}_{2} \mathrm{O}$ were prepared by dissolving the accurate weights in required volume of distilled water, and more dilute solution were obtained by accurate dilution.

- Acetate $\left(\mathrm{pH}_{1-2}\right)$ and Universal $\left(\mathrm{pH}_{2-12}\right)$ and buffer solutions [20] were prepared

\section{Synthesis of the solid complexes}

Azodyes complexes of $\mathrm{Cu}(\mathrm{II})$ and $\mathrm{Zn}(\mathrm{II})$ were prepared in a similar manner as described [21]. Thus, (0.004 mol) of each metal ions was added to a hot solution of the dyes $(0.008 \mathrm{~mol})$ in ethanol $(70 \mathrm{ml})$ and the resulting mixture was refluxed for $1 \mathrm{~h}$. A dark violet precipitates separated, which were collected by filtration, and recrystallized from mixture of ethanol : chloroform $(1: 3 \mathrm{v} / \mathrm{v})$. 


\section{Results and Discussion}

The analytical and physical data of the $\mathrm{L}-\mathrm{Cu}^{2+}$ and $\mathrm{L}-\mathrm{Zn}^{2+}$ complexes are presented in Table 1. Elemental analysis and continues variation method of the complexes indicate the stoichiometry to be $1: 2$ (metal: ligand).

Table 1: Analytical and physical data of complexes.

\begin{tabular}{|c|c|c|c|c|c|c|c|c|}
\hline \multirow[t]{2}{*}{ Comp } & \multirow{2}{*}{$\begin{array}{l}\text { Molecular Formula ( } \\
\text { M.wt.) }\end{array}$} & \multirow[t]{2}{*}{ Color } & \multirow{2}{*}{$\begin{array}{l}\text { M.P } \\
{ }^{\circ} \mathrm{C}\end{array}$} & \multicolumn{4}{|c|}{$\begin{array}{l}\text { Elemental Analysis } \\
\text { Found (Calc.) }\end{array}$} & \multirow[t]{2}{*}{$\begin{array}{c}\text { Cond. } \\
\mathrm{S} \mathrm{cm}^{2} \mathrm{~mol}^{-1}\end{array}$} \\
\hline & & & & $\% \mathrm{C}$ & $\% \mathrm{H}$ & $\% \mathbf{N}$ & & \\
\hline $\mathrm{L}-\mathrm{Cu}^{2+}$ & $\begin{array}{c}\mathrm{C}_{40} \mathrm{H}_{32} \mathrm{~N}_{10} \mathrm{O}_{4} \mathrm{Cu} \\
(779.5)\end{array}$ & Violet & 260 & $\begin{array}{l}61.33 \\
(61.58)\end{array}$ & $\begin{array}{r}3.09 \\
(4.11)\end{array}$ & $\begin{array}{r}18.01 \\
(17.96)\end{array}$ & $\begin{array}{r}8.16 \\
(8.14)\end{array}$ & 15.6 \\
\hline $\mathrm{L}-\mathrm{Zn}^{2+}$ & $\begin{array}{c}\mathrm{C}_{44} \mathrm{H}_{42} \mathrm{~N}_{10} \mathrm{O}_{6} \mathrm{Zn} \\
(871.4)\end{array}$ & Violet & 285 & $\begin{array}{l}61.43 \\
(60.59)\end{array}$ & $\begin{array}{r}4.98 \\
(4.82)\end{array}$ & $\begin{array}{r}16.44 \\
(16.07)\end{array}$ & $\begin{array}{r}7.62 \\
(7.51)\end{array}$ & 18.02 \\
\hline
\end{tabular}

The IR has proven to be, in this particular case, a suitable technique to give enough information to elucidate the way of bonding of the ligands. Thus a detailed interpretation of IR spectra of these and the effect of binding of metal ions on the vibration frequencies of the free dye ( Table 2).

Table -2: The I.R spectral data of ( $\mathrm{KBr}$ disk )

\begin{tabular}{|c|c|c|c|c|c|c|}
\hline Comp. & $\boldsymbol{v}(\mathbf{O H})$ & $\boldsymbol{v}(\mathbf{N}=\mathbf{N})$ & $\boldsymbol{v}(\mathbf{C =} \mathbf{O})$ & $\mathbf{u}(\mathbf{C}=\mathbf{N})$ & $\mathbf{u}(\mathbf{M}-\mathbf{O})$ & $\mathbf{u}(\mathbf{M}-\mathbf{N})$ \\
\hline $\mathbf{L}$ & $\mathbf{3 4 0 2}$ & $\mathbf{1 4 7 0}$ & $\mathbf{1 6 6 0}$ & $\mathbf{1 6 2 0}$ & -- & - \\
\hline${\mathrm{L}-C \mathrm{Cu}^{2+}}^{2+}$ & 3990 & 1470 & 1670 & 1590 & 510 & 410 \\
\hline $\mathrm{L}-\mathrm{Zn}^{2+}$ & 3988 & 1470 & 1665 & 1595 & 495 & 425 \\
\hline
\end{tabular}

The IR spectrum of the ligand (Fig.(1)) exhibited broad band at $(3402 \mathrm{~cm}-1)$ was assigned to the stretching vibration of $\mathrm{u}(\mathrm{OH})$ of the carboxyl and phenol[22,]. Strong band in the ligand spectrum was observed at $(1660 \mathrm{~cm}-1)$ ascribed to the $\mathrm{U}(\mathrm{C}=\mathrm{O})$ for the carboxyl group. Significant change in the position to higher frequency was also observed on complexation with metal ion. The strong band in the free ligand spectrum at $(1604 \mathrm{~cm}-1)$ due to $\mathrm{u}(\mathrm{CO})$ asymmetric vibration, significant change in the intensity and in position to lower frequency was observed on complexation with metal ion.

The IR spectra showed that values of $-\mathrm{N}=\mathrm{N}$ - stretching frequency $(1501 \mathrm{~cm} P-1 P)$ in dye $\mathrm{L} R \mathbf{1} R$ and its synthesized complexes and $(1504 \mathrm{~cm} P-1 P)$ in dye $\mathbf{L} R \mathbf{2} R$ and its synthesized complexes remain practically unchanged indicating that $\mathrm{N}=\mathrm{N}-$ group have no part in coordination whereas the carbonyl group $\mathrm{C}=\mathrm{O}$ stretching frequency $(1668 \mathrm{~cm} P-1 P)$ in dye $\mathbf{L} R \mathbf{2} R$ have unchanged values as well, indicating that carbonyl group is not taking part in coordination. However, the high changing in the shape and the position of $\mathrm{O}-\mathrm{H}$ stretching and $\mathrm{O}-\mathrm{H}$ in plane bending and $\mathrm{O}-\mathrm{H}$ out of plane bending and changing in the position of $\mathrm{C}=\mathrm{N}$ stretching in pyridyl group as compared to spectra of free ligands indicate that $(\mathrm{O}-\mathrm{H}$ group and $\mathrm{N}$ atom) in 8-hydroxyquinoline are involved in coordination between azo-dye (LR1 $R$ ) with their synthesized complexes. In addition, in the complexes (, $\left.\mathbf{L} R \mathbf{R} R-\mathbf{C u} ; \mathbf{L}_{\mathbf{1}}-\mathbf{Z n}\right)$ we obtained two new bands in every complex and they are assigned to $\mathrm{M}-\mathrm{N}$ stretching , $\mathrm{M}-\mathrm{O}$ stretching frequency the IR spectra of the Zinc (II) and Copper (II) complexes indicate that phenolic $\mathrm{OH}$ has deprotonated during complexation. Band due to $\mathrm{v}(\mathrm{O}-\mathrm{H})$ becomes further broadened and increased in intensity in the complexes indicating non participation of phenolic oxygen in complexation. The broadening of $v(\mathrm{O}-\mathrm{H})$ vibrations may be due to the overlapping with absorption due to lattice water coordinated water [22] 


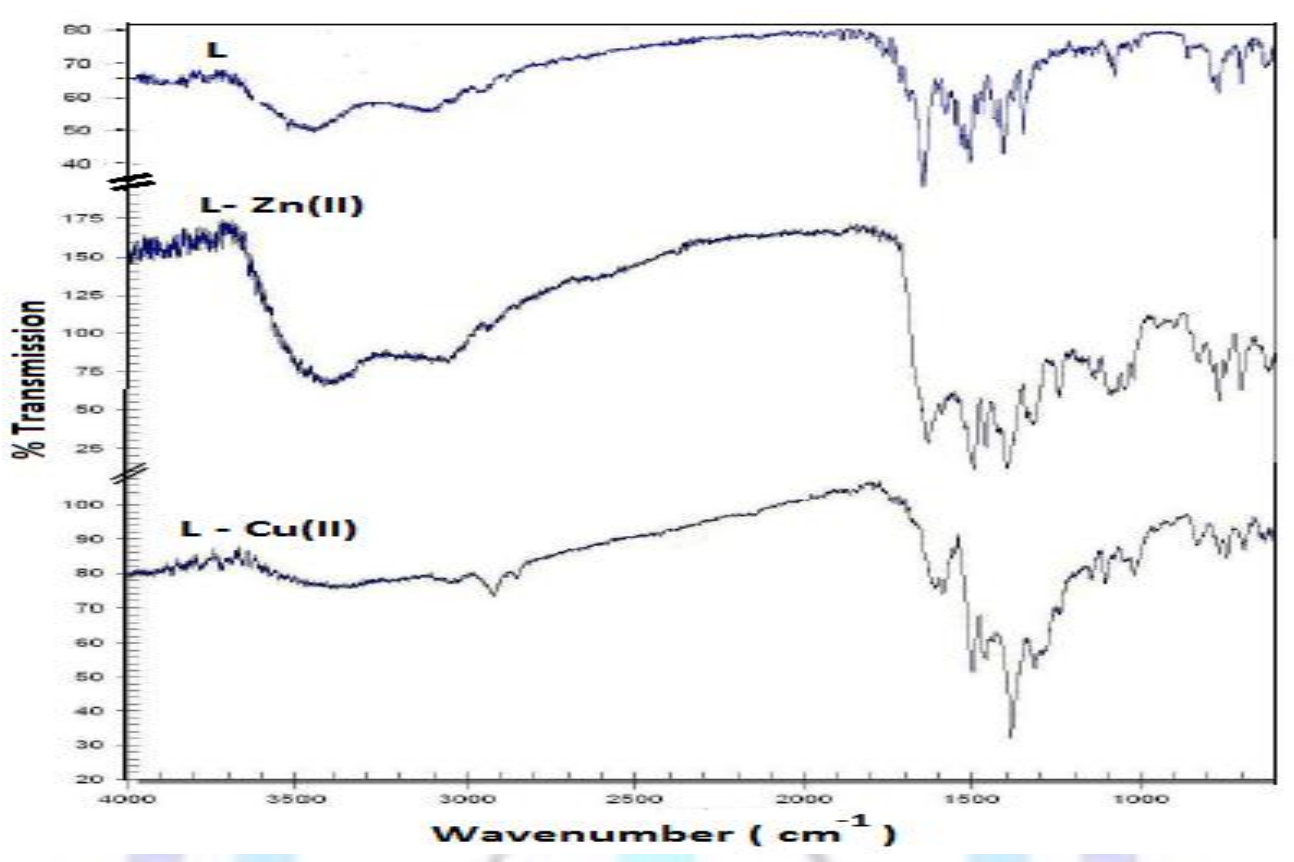

Fig-1: IR specra of $L_{1}$ and its complexes

\section{Complex formation studies}

The complexes of $\mathrm{Cu}^{2+}$ and $\mathrm{Zn}^{2+}$ ions with $\mathrm{L}$ solutions were always performed. These complexes were identified optimum conditions for the composition of these complexes ( time, $\mathrm{pH}$, temperature and sequence of addition effects ).

\section{pH-effect}

The absorption spectra of $\mathrm{L}-\mathrm{Cu}^{2+}$ and $\mathrm{L}-\mathrm{Zn}^{2+}$ were studied at $\mathrm{pH}$ values range $(0.65-12)$ (Fig. 2), by using acetate and universal buffer solutions in the range of wavelength $250-600 \mathrm{~nm}$. It was found the $\mathrm{pH} 12$ is the suitable value for giving highest absorbance due to the formation of basic form (anionic form) which gives essayer condition for attraction with cations.

The interaction of $\mathrm{Cu}^{2+}$ and $\mathrm{Zn}^{2+}$ ions with the dye $(\mathrm{L})$ manifest itself in the absorption spectra by the appearance of a peak in the range ( 510 and $480 \mathrm{~nm}$ ) for $\mathrm{L}-\mathrm{Cu}^{2+}$ and $\mathrm{L}-\mathrm{Zn}^{2+}$ complexes respectively. A great red shift in the visible region was detected in the complex solutions spectra with respect to that of the free dye $\left(\lambda_{\max }=390 \mathrm{~nm}\right.$.). The shift in the $\left(\lambda_{\max }\right)$ gave a good indication for complex formation. (Fig.-3 ). 


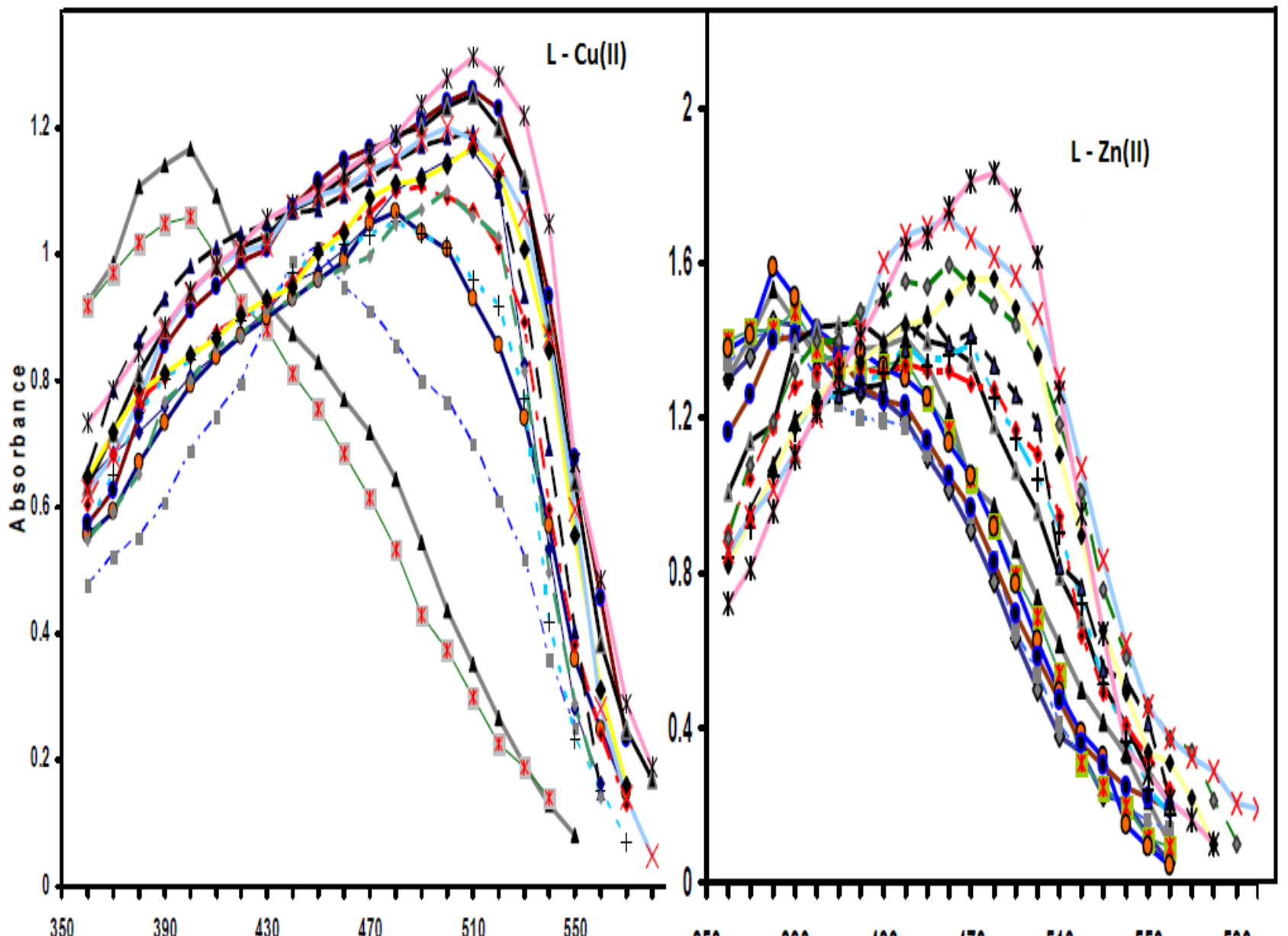

$350 \quad 390 \quad 430 \quad 470 \quad 510 \quad 550$

Wavelength $(\mathrm{nm}$. )

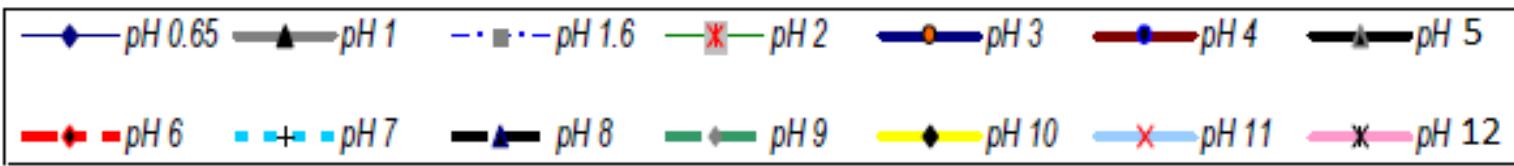

Fig.-2: Absorption spectra of $\mathrm{L}-\mathrm{Cu}^{2+} \& \mathrm{~L}-\mathrm{Zn}^{2}$ complexes at different $\mathrm{pH}$ values, $\left[\mathrm{Cu}^{2+}\right]=\left[\mathrm{Zn}^{2+}\right]=[\mathrm{L}]=8 \times 10^{-5} \mathrm{M}$

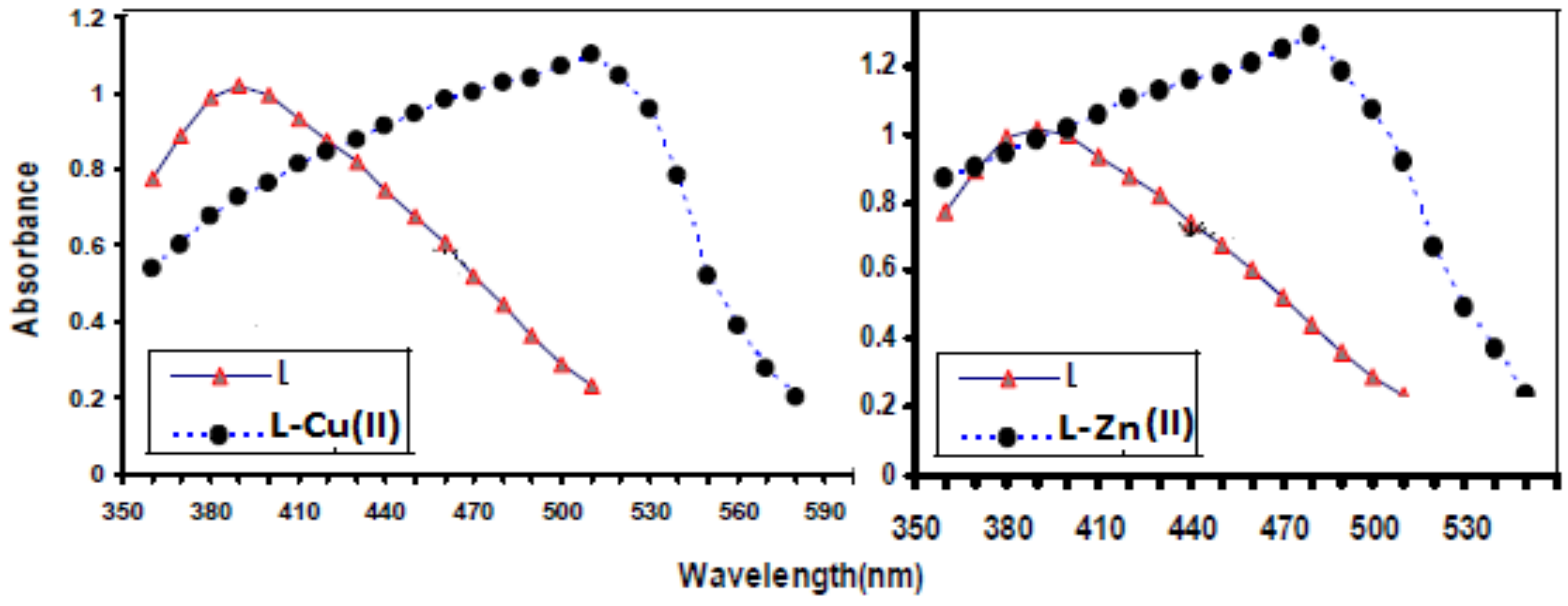

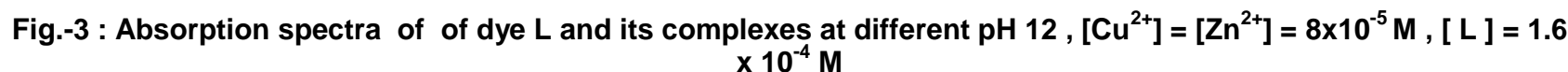




\section{Time effect}

It was found from Fig. (4) the absorbencies are constant from 15 min up to $48 \mathrm{hrs}$. that means the complex is of high stability .

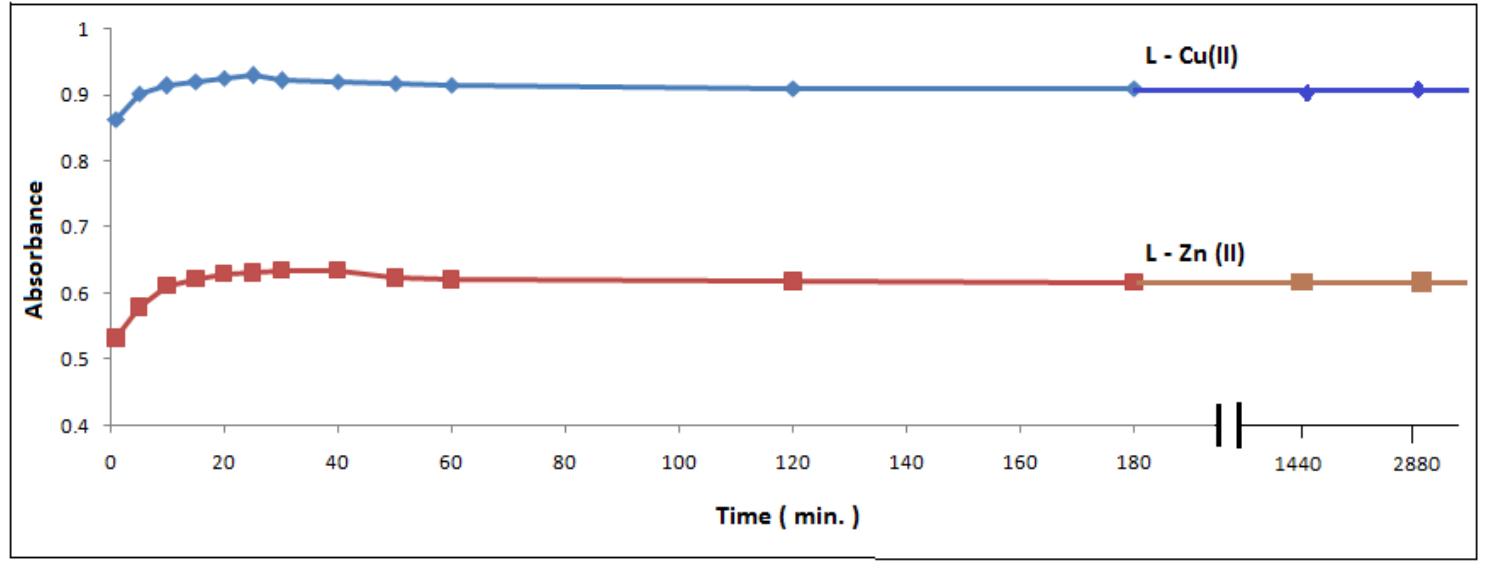

Fig.-4 : Effect of time on the absorbance of azo dyes complexes at $\lambda_{\max }$ of each complex

$$
\left[\mathrm{Cu}^{2+}\right]=\left[\mathrm{Zn}^{2+}\right]=[\mathrm{L}]=8 \times 10^{-5} \mathrm{M}
$$

\section{Squence of additions}

It was found from Table -3 , that the sequence $\left(\mathrm{Dye}+\mathrm{pH}_{12}+\mathrm{M}^{2+}\right.$ ) having heighest absorbance value of the azo dyes complexes. This attributed to the effect of alkaline medium of buffer solution (anionic form ), which makes the dye suitable for accepting metal ions .

Table-3: Sequence of addition of reagents $\left([\mathrm{L}]=\left[\mathrm{Cu}^{2+}\right]=\left[\mathrm{Zn}^{2+}\right]=8 \times 10^{-3} \mathrm{M}\right.$

\begin{tabular}{|c|c|c|c|}
\hline \multirow{2}{*}{} & \multirow{2}{*}{ Sequence of addition } & $\mathbf{2}$ Absorbance at $\boldsymbol{\Lambda}_{\max }$ \\
\cline { 2 - 4 } & Dye $+\mathrm{M}^{2+}+\mathrm{pH}_{12}$ & 0.732 & $\mathbf{L}-\mathbf{Z n}^{2+}$ \\
\hline $\mathbf{1}$ & Dye $+\mathrm{pH}_{12}+\mathrm{M}^{2+}$ & 0.821 & 1.003 \\
\hline $\mathbf{3}$ & $\mathrm{M}^{2+}+\mathrm{pH}_{12}+$ Dye & 0.791 & 1.105 \\
\hline
\end{tabular}

\section{Temperature effect}

Fig.- 5 shows the effect of temperature range $\left(10-90 \mathrm{C}^{\circ}\right)$ on the absorbance of each complex. It was found that, the complexes be stable up to $40 \mathrm{C}^{\circ}$ ( i.e. very slightly change in absorbance ). Up this temperature $\left(40 \mathrm{C}^{\circ}\right)$ the complexes are unstable may be for decomposition of complexes .

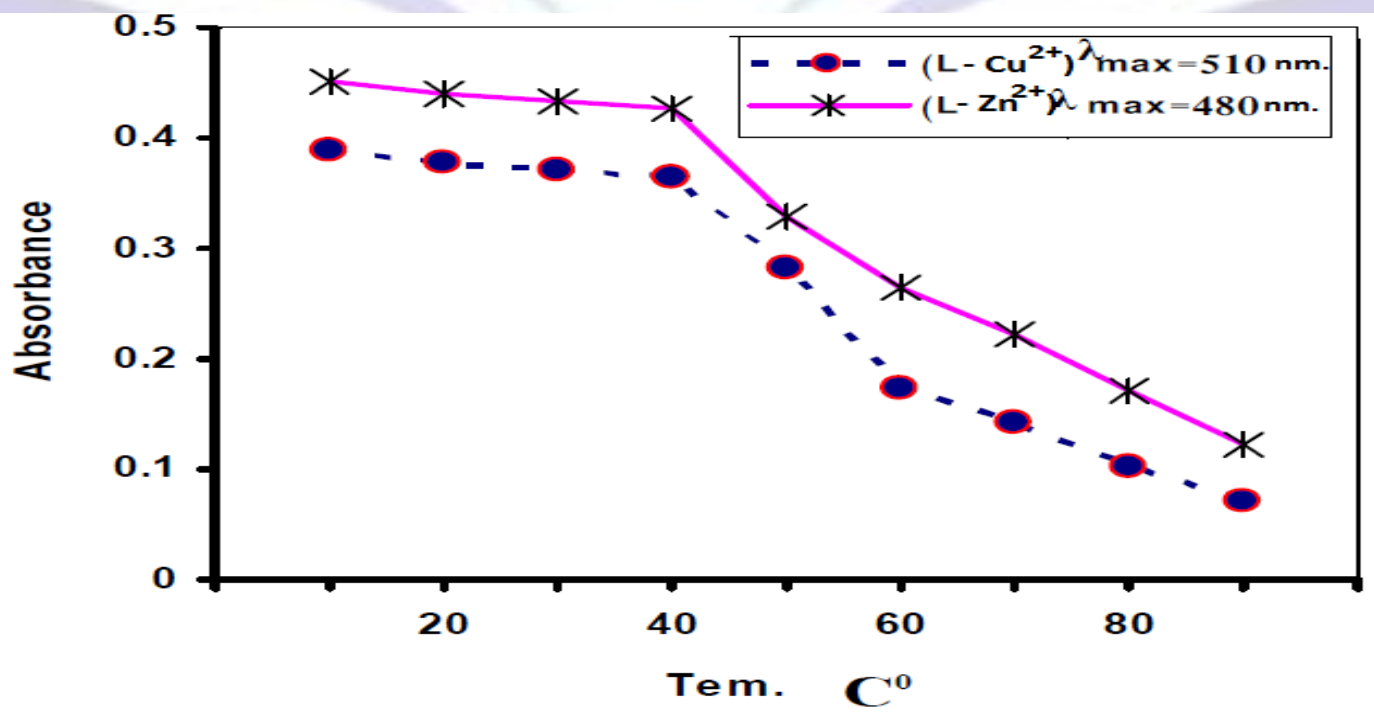

Fig. - 5: Temperature effect on the absorbance of azo dyes complexes $\left[\mathrm{Cu}^{2+}\right]=\left[\mathrm{Zn}{ }^{2+}\right]=[\mathrm{L}]=8 \times 10^{-5} \mathrm{M}$ 


\section{The composition of the complexes (stoichiometry)}

The composition of the complexes formed has been established by continues variation and mole ratio methods [23]. From Figs. -6 \& 7 , it was found that the $\left(\mathrm{M}^{2+}\right.$ : azo dye) equal to $(1: 2)$.
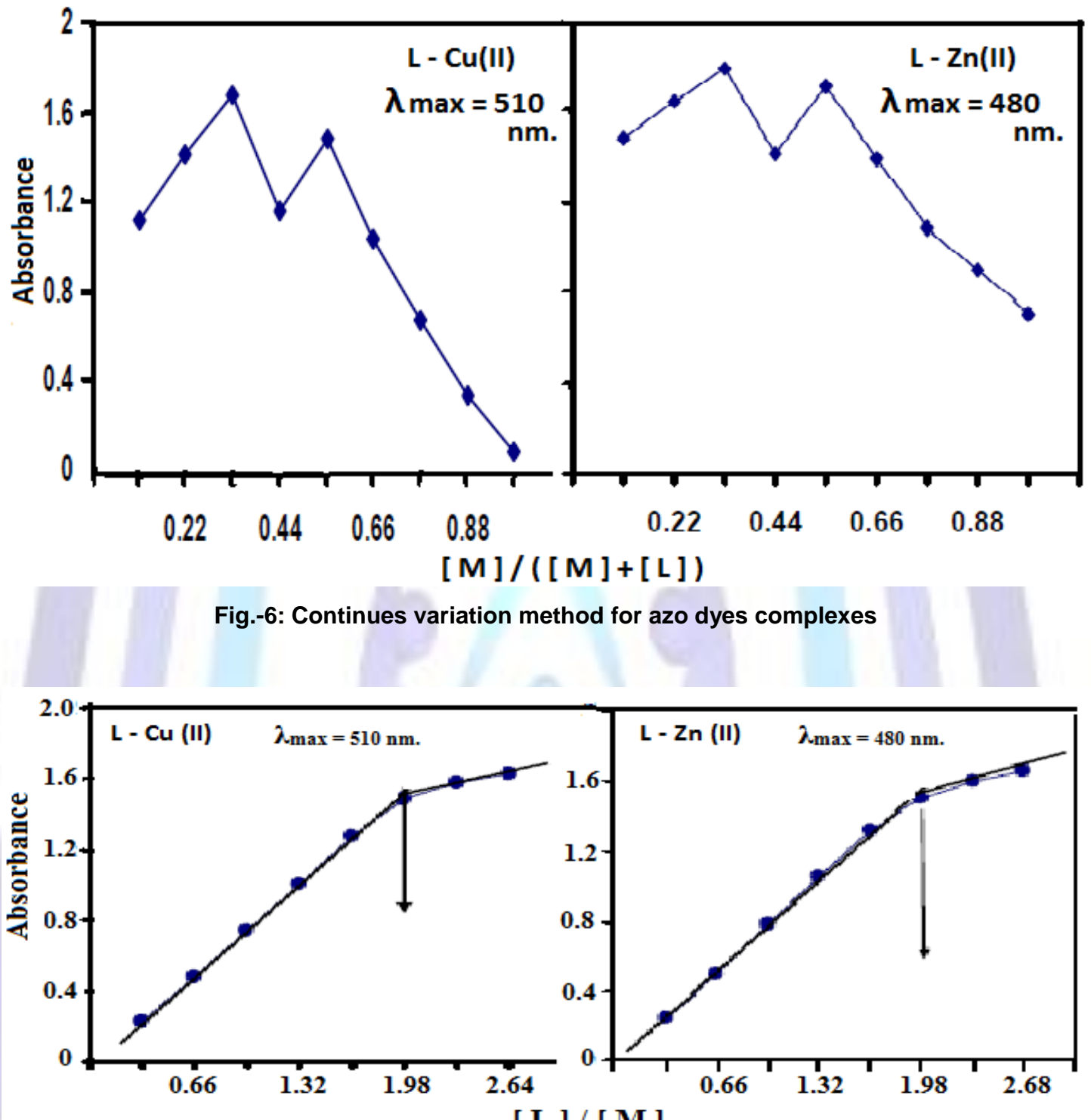

$[\mathbf{L}] /[\mathbf{M}]$

Fig.-7: Mole ratio method for azo dyes complexes

\section{Beer's law and sensitivity}

To get better results for beer's law, the optimum blank composition technique [ 23 ] was applied ( i.e. using unreacted dye as blank solution from knowledgement of stoichiometry of complexes )

The calibration curve ( Fig.- 8 ) shows that Beer's law is obeyed up to concentration range 8.87 and $7.80 \mu \mathrm{g} \mathrm{ml}{ }^{-1}$ for $\mathrm{Cu}(\mathrm{II})$ and $\mathrm{Zn}(\mathrm{II})$ in $\mathrm{L}-\mathrm{Cu}^{2+}$ and $\mathrm{L}-\mathrm{Zn}^{2+}$ complexes respectively. Table ( 4 ) shows the data obtained, that represented by the molar absorbitivity coefficient $\left(\varepsilon, \mathrm{L} \cdot \mathrm{mol}^{-1} . \mathrm{cm}^{-1}\right)$ and sensitive index $\left(\mathrm{S}, \mu \mathrm{g} . \mathrm{cm}^{-2}\right)$, and the detection limit ( DL $\left.\mu \mathrm{g} \cdot \mathrm{ml}\right)$ of the complexes. With high precision that represented by the results of standard deviation (S.D), and high linearity of Beer's law which represent by the correlation coefficient $(r)$ which is nearly to unity. From a table, it was found the method of high precision and high sensitivity. 
Table -4: Some results obtained from Beer's law

\begin{tabular}{|r|c|c|c|c|c|}
\hline Complex & $\begin{array}{c}\varepsilon \times \mathbf{x 1}^{4} \\
\text { I/mol.cm }\end{array}$ & S.D & $\mathbf{S ~} \boldsymbol{\mu g} / \mathbf{m l}$ & $\mathbf{r}$ & Beer's law limit ppm \\
\hline L-Cu(II) & 1.2 & 0.010 & 0.0053 & 0.9857 & $0.131-8.87$ \\
\hline L-Zn(II) & 1.6 & 0.012 & 0.0042 & 0.9459 & $0.189-7.80$ \\
\hline
\end{tabular}
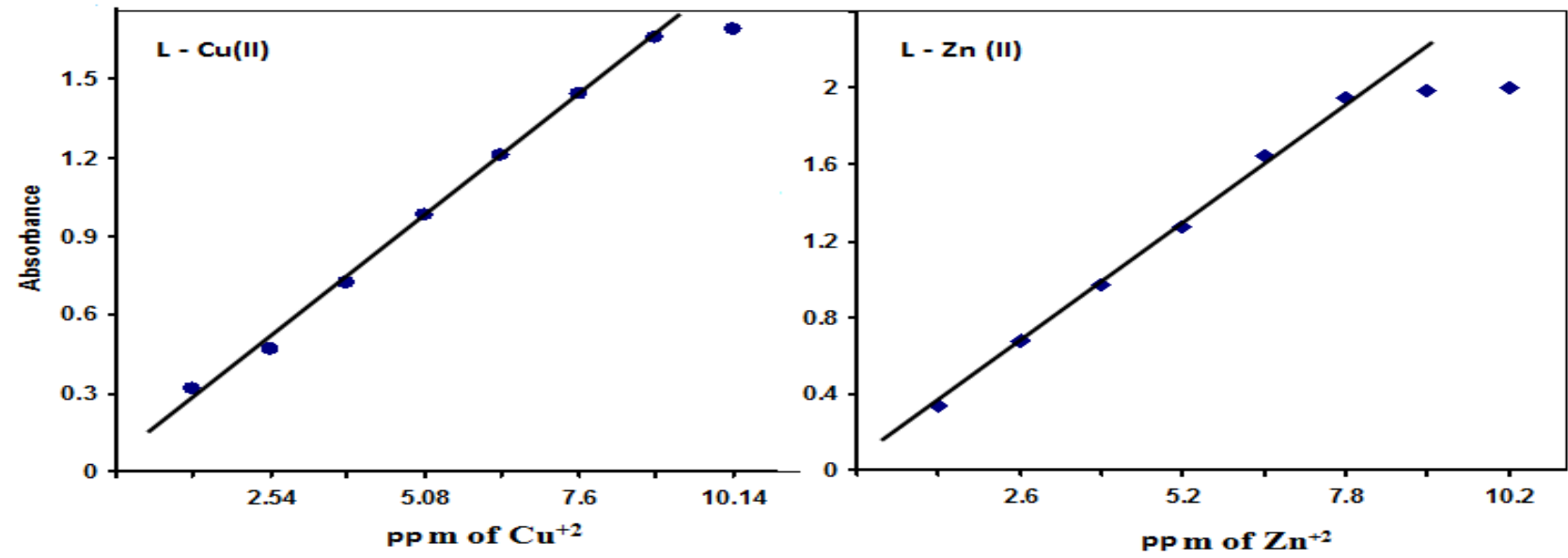

Fig.-8: The calibration curves of $\mathrm{L}-\mathrm{Cu}^{2+}$ and $\mathrm{L}-\mathrm{Zn}^{2+}$ complexes at $\lambda_{\max }$

\section{Interference effect of foreign ions}

It was so important to study the interference the effect of foreign ions in different ranges of concentration . From Table- 5 , it was found that ions $\left(\mathrm{Cl}^{-}, \mathrm{Pb}^{+2}, \mathrm{Bi}^{+3}, \mathrm{Cd}^{+2}, \mathrm{Na}^{+}, \mathrm{Ca}^{+2}, \mathrm{Ni}^{+2}, \mathrm{Mg}^{+2}, \mathrm{Co}^{+2}, \mathrm{VO}_{3}{ }^{5+}\right.$, tartaric acid , ascorbic acid , citric acid , and sodium thiosulphate ) did not effected on the absorbance (that means not interfered) of $\mathrm{L}_{-} \mathrm{Cu}^{2+}$ complex in all ranges of concentrations. While the other ions $\left(\mathrm{Ag}^{+}, \mathrm{Al}^{+3}, \mathrm{Fe}^{+2}, \mathrm{Fe}^{+3}, \mathrm{Cr}^{+3}, \mathrm{Zn}^{+2}\right.$ and EDTA ) were done.

In case of $\mathrm{L}-\mathrm{Zn}^{2+}$ complex, the ions $\left(\mathrm{Cl}^{-}, \mathrm{Pb}^{+2}, \mathrm{Bi}^{+3}, \mathrm{Cd}^{+2}, \mathrm{Na}^{+}, \mathrm{Ca}^{+2}, \mathrm{Ni}^{+2}, \mathrm{Mg}^{+2} \mathrm{VO}_{3}{ }^{5+}\right.$, tartaric acid, ascorbic acid, citric acid, and sodium thiosulphate) were not interfered in all ranges of concentrations . while the other ions $\left(\mathrm{Ag}^{+}, \mathrm{Al}^{+3}, \mathrm{Fe}^{+2}, \mathrm{Fe}^{+3}\right.$ $\mathrm{Cr}^{+3}, \mathrm{Co}^{+2}, \mathrm{Cu}^{+2}$ and EDTA ) were interfered in all ranges of concentrations, except for ions $\left(\mathrm{Al}^{+3}, \mathrm{Fe}^{+2}, \mathrm{Fe}^{+3}\right.$ and $\left.\mathrm{EDTA}\right)$ were interfered only in 5 -fold and 10 - fold concentrations .

Table - 5: The absorbance of complexes in presence of foreign ions $\left(\left[\mathrm{Zn}^{2+}\right]=\left[\mathrm{Cu}^{2+}\right]=[\mathrm{L}]=8 \times 10^{-5} \mathrm{M}\right.$

\begin{tabular}{|c|c|c|c|c|c|c|}
\hline \multirow[t]{2}{*}{ Interfering ions } & \multicolumn{3}{|c|}{ Absorbance of L-Cu(II) ,510 nm. } & \multicolumn{3}{|c|}{ Absorbance of L-Zn(II) , $480 \mathrm{~nm}$. } \\
\hline & 1 - fold & 5 - fold & 10 - fold & 1 - fold & 5 - fold & 10 - fold \\
\hline $\mathrm{Ag}^{+}$ & 0.921 & 0.9431 & 0.974 & 1.311 & 1.295 & 1.354 \\
\hline $\mathrm{Al}^{+3}$ & 0.941 & 0.955 & 0.975 & 1.245 & 1.277 & 1.301 \\
\hline $\mathrm{Co}^{+2}$ & 0.741 & 0.752 & 0.778 & 1.301 & 1.311 & 1.335 \\
\hline $\mathrm{Cr}^{+3}$ & 0.902 & 0.919 & 0.945 & 0.940 & 0.972 & 1.012 \\
\hline $\mathrm{Fe}^{+3}$ & 1.012 & 1.093 & 1.145 & 1.245 & 1.301 & 1.348 \\
\hline $\mathrm{Fe}^{+2}$ & 0.941 & 0.978 & 1.081 & 1.241 & 1.281 & 1.309 \\
\hline $\mathrm{Mg}^{+2}$ & 0.830 & 0.805 & 0.805 & 1.121 & 1.142 & 1.131 \\
\hline $\mathrm{Ni}^{+2}$ & 0.819 & 0.824 & 0.851 & 1.109 & 1.108 & 1.107 \\
\hline $\mathrm{Ca}^{+2}$ & 0.807 & 0.813 & 0.810 & 1.101 & 1.107 & 1.105 \\
\hline $\mathrm{Na}^{+}$ & 0.801 & 0.801 & 0.803 & 1.103 & 1.109 & 1.107 \\
\hline
\end{tabular}




\begin{tabular}{|c|c|c|c|c|c|c|}
\hline $\mathbf{C l}^{-}$ & 0.820 & 0.822 & 0.830 & 1.104 & 1.045 & 1.047 \\
\hline $\mathbf{C d}^{+2}$ & 0.740 & 0.790 & 0.780 & 1.045 & 1.055 & 1.043 \\
\hline $\mathbf{B i}^{+3}$ & 0.801 & 0.780 & 0.790 & 1.100 & 1.051 & 1.030 \\
\hline $\mathbf{P b}^{+2}$ & 0.817 & 0.810 & 0.809 & 1.101 & 1.097 & 1.109 \\
\hline $\mathbf{V O}_{3}{ }^{++}$ & 0.811 & 0.815 & 0.822 & 1.109 & 1.151 & 1.110 \\
\hline EDTA & 1.013 & 1.071 & 1.100 & 1.230 & 1.291 & 1.310 \\
\hline Sodium thiosulphate & 0.815 & 0.811 & 0.819 & 1.101 & 1.107 & 1.108 \\
\hline Tartaric acid & 0.812 & 0.813 & 0.821 & 1.103 & 1.105 & 1.102 \\
\hline Citric acid & 0.817 & 0.815 & 0.812 & 1.101 & 1.108 & 1.109 \\
\hline Ascorbic acid & 0.809 & 0.811 & 0.823 & 1.102 & 1.105 & 1.103 \\
\hline $\mathbf{Z n}^{+2}$ & 0.981 & 1.1 & 1.18 & - & - & - \\
\hline $\mathbf{C u}^{+2}$ & - & - & - & 1.32 & 1.37 & 1.47 \\
\hline
\end{tabular}

The absorbance of $\mathrm{L}$ - Cu (II) complex in absence of foreign ions $=0.820$

The absorbance of $L-Z n$ (II) complex in absence of foreign ions $=1.105$

\section{Masking of interfering ions}

If each of the following interfering ion $\left(\mathrm{Ag}^{+}, \mathrm{Al}^{+3}, \mathrm{Cr}^{+3}, \mathrm{Zn}^{+2}, \mathrm{Fe}^{+2}\right.$ and $\left.\mathrm{Fe}^{+3}\right)$ is present separately with $\mathrm{Cu}^{2+}$ or $\mathrm{Zn}^{2+}$ ion, 0.01 mole of the following masking agents ( sodium thiosulphate, tartaric acid, ascorbic acid, citric acid, sodium thiosulphate and sodium thiosulphate) respectively. In case of EDTA, 0.15 mmole of $\left(\mathrm{VO}_{3}\right)+{ }^{5}$ was added.

It was found that the absorbance of $\mathrm{L}-\mathrm{Cu}^{2+}$ and $\mathrm{L}-\mathrm{Zn}^{2+}$ complexes were affected by \pm 0.009 and \pm 0.007 respectively.

\section{The stability of the complexes}

The stability constants (formation constant) of complexes $\mathrm{Cu}^{2+}$ and $\mathrm{Zn}^{2+}$ ions with $\mathrm{L}$ were determined by using Corresponding solutions method [25], which depends on aid of half- value method [26]. This method required two series of solutions of total metal ion concentration $\mathrm{C}_{1 \mathrm{M}}=8 \times 10^{-4} \mathrm{M}$ (concentrated series) and $\mathrm{C}_{2 \mathrm{M}}=4 \times 10^{-4} \mathrm{M}$ (diluted series), where $\mathrm{C}_{1 \mathrm{M}}>\mathrm{C}_{2 \mathrm{M}}$ and varying ligand concentrations $\mathrm{C}_{1 \mathrm{~L}}\left(0.2-2 \times 10^{-4}\right)$ and $\mathrm{C}_{2 \mathrm{~L}}\left(0.1-1.2 \times 10^{-4} \mathrm{M}\right)$. Then the absorbance of diluted series was multiplied by the factor $\left(\mathrm{C}_{1 \mathrm{M}} / \mathrm{C}_{2 \mathrm{M}}\right.$ which equal 2$)$. The corresponding solutions are those which have the same absorbance at different ligand (dye ) concentration. From the absorbance - $C_{L}$ plots ( Fig.- 9 ) , many pairs of $C_{1 L}$ and $\mathrm{C}_{2 L}$ consequently, $\tilde{\mathrm{n}}$ (complex formation function) and $[\mathrm{L}]$ (free ligand concentration ) can be determined where :

$\tilde{n}=\left(C_{1 L}-C_{2 L}\right) /\left(C_{1 M}-C_{2 M}\right) \quad$ and $\quad[L]=\left(C_{1 M} C_{2 L}-C_{2 M} C_{1 L}\right) /\left(C_{1 M}-C_{2 M}\right)$

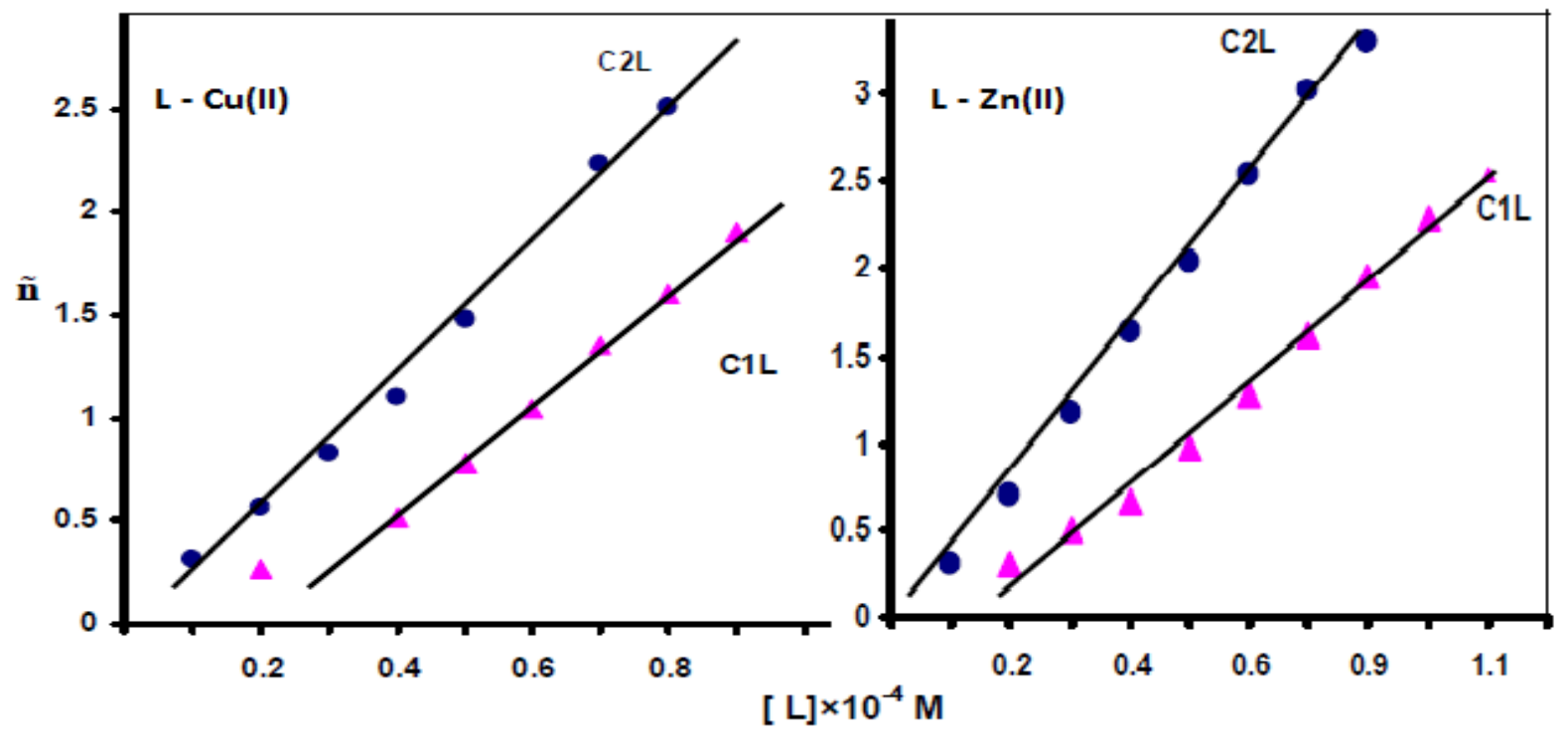

Fig.-9 : Absorbance $-C_{L}$ plot of complexes $\mathrm{Cu}^{2+}$ and $\mathrm{Zn}^{2+}$ ions with $\mathrm{L}$ at $\lambda_{\max }$ of each of them 
Then $\tilde{n}-p L$ was plotted (Fig.-10) and by using the half value method, the $\log \beta_{1}$ and $\log \beta_{2}$ are obtained (Table -6$)$. When $\tilde{n}=0.5$ gives $\log \beta_{1}\left(\log K_{1}\right)$ and $\tilde{n}=1.5$ gives $\log \beta_{2}\left(\log K_{1}+\log K_{2}\right)$

(Where $K$ and $\beta$ are step stability and overall stability constants).
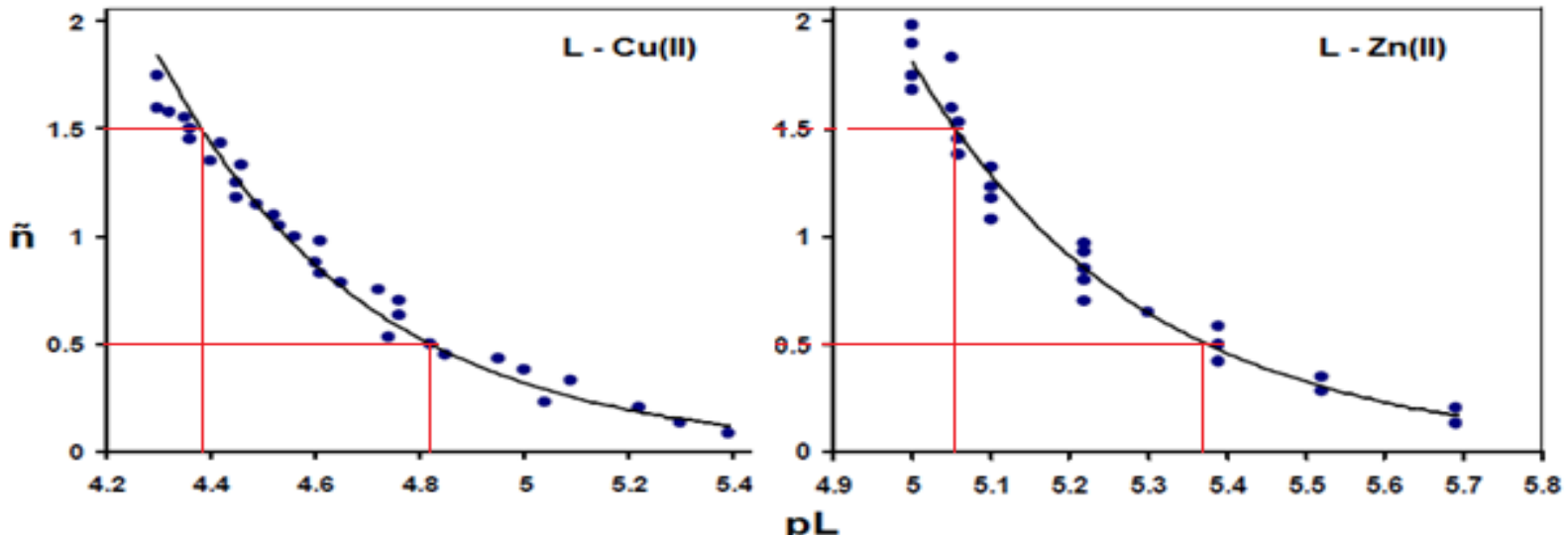

Fig.-10: $\tilde{\mathrm{n}}-\mathrm{pL}$ curves for complexes $\mathrm{Cu}^{2+}$ and $\mathrm{Zn}^{2+}$ ions with $\mathrm{L}$

Table -6: $\log K$ and $\log \beta$ values for complexes of $\mathrm{Cu}^{2+}$ and $\mathrm{Zn}^{2+}$ ions with $\mathrm{L}$ complexes

\begin{tabular}{|c|c|c|}
\hline \multirow{2}{*}{$\begin{array}{c}\text { Log } \mathrm{K} \text { and } \log \beta \\
\text { Values }\end{array}$} & $\mathrm{L}-\mathrm{Cu}(\mathrm{II})$ & $\mathrm{L}-\mathrm{Zn}(\mathrm{II})$ \\
\cline { 2 - 3 } $\log \mathrm{K}_{\mathbf{1}}=\log \boldsymbol{\beta}_{1}$ & 4.38 & 5.06 \\
\hline $\log \mathrm{K}_{2}$ & 4.88 & 5.37 \\
\hline $\log \beta_{2}$ & 9.26 & 10.43 \\
\hline
\end{tabular}

It was found from Table -6 , the sequence of azo dyes complexes stability are $L-\mathrm{Zn}(\mathrm{II})>\mathrm{L}-\mathrm{Cu}$ (II) and also found that $\log \mathrm{K}_{1}$ is nearly equal to the $\log \mathrm{K}_{2}$, that means the azo dyes complex reaction is spontaneous and happened in one step .

\section{Structural interpretation}

From the C.H.N. analysis, Atomic analysis for $\mathrm{Cu}$ and $\mathrm{Zn}$, IR technique and conductivity measurements, the structure of complexes $\mathrm{L}-\mathrm{Zn}(\mathrm{II})$ and $\mathrm{L}-\mathrm{Cu}(\mathrm{II})$ were suggested. The $\mathrm{Zn}^{2+}$ and $\mathrm{Cu}^{2+}$ ions have been coordinated through phenolic $\mathrm{O}$ atom and $\mathrm{N}$ atom of pyridine of 8-hydroxyquinoline of the azo dye $\mathrm{L}$ by forming square planer structure with respect to $\mathrm{Cu}^{2+}$ ions and octahedral structure with respect to $\mathrm{Zn}^{2+}$ ions ( in case of $\mathrm{L}-\mathrm{Zn}$ complex two molecules of ethanol have been coordinated with metal ion ). Consequently, the proposed general structures are shown in

Schemes 2 .

Scheme 2 


\section{Biological activity of the complexes}

Table -7 and Fig. (11) show the comparison of biological activities of the dye $(L)$ and its complexes with $\mathrm{Cu}^{2+}$ and $\mathrm{Zn}^{2+}$ ions on two types of bacteria (Escherichia Coli and Clostridium Botulinum). It was found that the dye and its complexes having only biological activity on Clostridium Botulinum, while no effect on Escherichia Coli, this because may be thickness of cell's wall slightly hard ( high lipidely ) that resists the chemical substances to enter the cell. It was also found that quince of biological activity of free dye, $\mathrm{L}-\mathrm{Cu}$ (II) complex and L- Zn(II) complex as; $\mathrm{L}-\mathrm{Cu}$ (II) $>\mathrm{L}-\mathrm{Zn}$ (II) $>\mathrm{Dye}$ ( $\mathrm{L}$ ) in two concentrations 1 and $5 \mathrm{mg} \cdot \mathrm{ml}^{-1}$.

Table - 7 : The biological activity of free dye and its complexes on Escherichia Coli and Clostridium Botulinum) with diameter (in $\mathrm{cm}$ ) of effected zone

\begin{tabular}{|c|c|c|c|}
\hline Compound & Concentration $\mathbf{~ m g . m I ~}^{-1}$ & $\begin{array}{c}\text { Clostridium Botulinum ( cm } \\
\text { ) }\end{array}$ & $\begin{array}{c}\text { Escherichia Coli } \\
\mathbf{c m})\end{array}$ \\
\hline Dye ( L ) & 1 & 1.5 & 0 \\
\hline L-Cu(II) & 1 & 2.9 & 0 \\
\hline L-Zn(II) & 1 & 2.2 & 0 \\
\hline Dye ( L ) & 5 & 2 & 0 \\
\hline L-Cu(II) & 5 & 3.5 & 0 \\
\hline L-Zn(II) & 5 & 2.8 & 0 \\
\hline
\end{tabular}
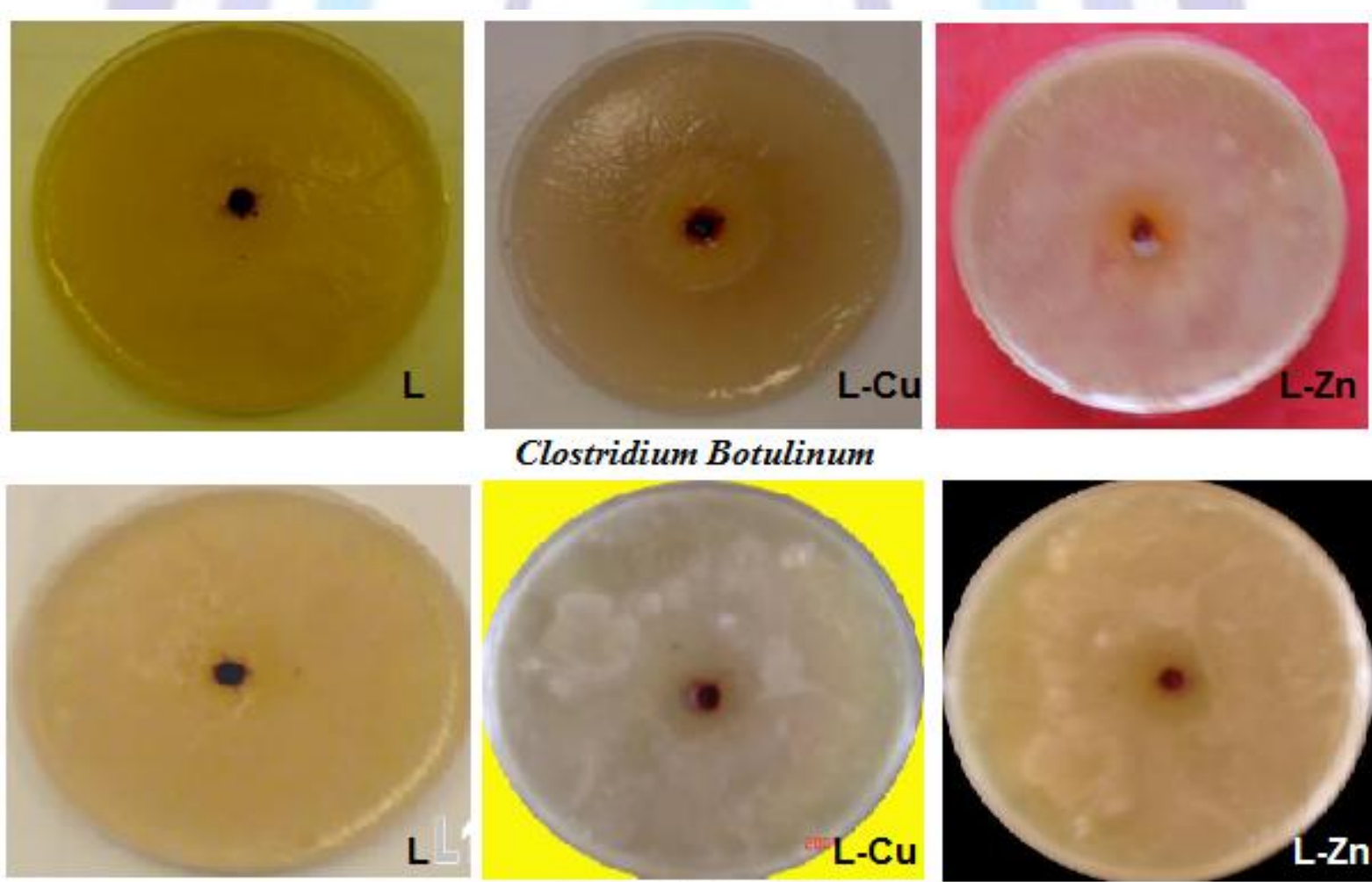

\section{Clostridium Botulinum}

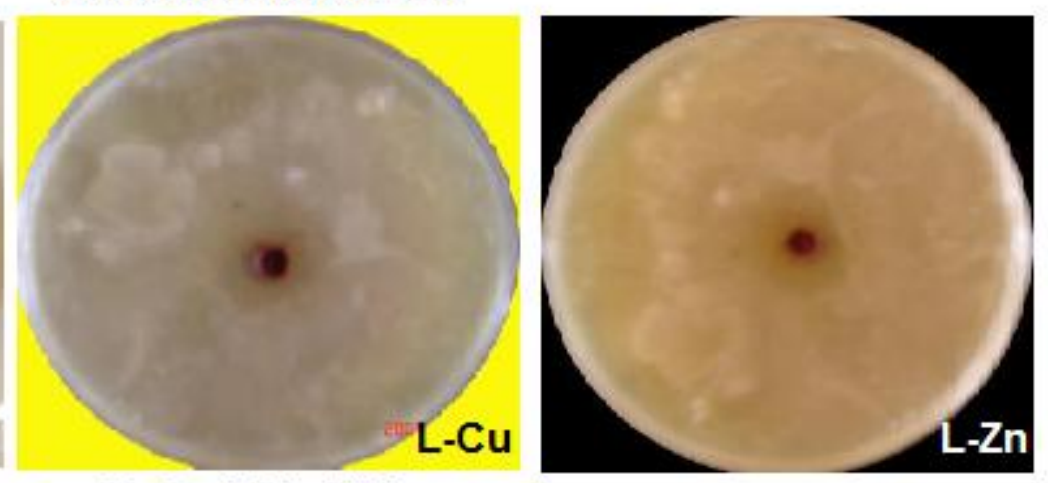

\section{Escherichia Coli}

Fig.-11 : The effect of Dye and its complexes on Escherichia Coli and Clostridium Botulinu in case of concentration of $1 \mathrm{mg} \cdot \mathrm{ml}^{-1}$ 


\section{References}

[1] Bulent Kikan and Ramazan GUP, Turk J Chem, 32, 9 - 17 (2008).

[2] Valentina,C ,TURCAŞ1 Ion SEBE2, U.P.B. Sci. Bull., Series B, 74, 109-118 (2012)

[3] Marczenko,Z.," Spectrophotometric Determination of Elements " Ellis Horword Publisher (1976)

[4] Badea, M., Olar, R., Cristurean, E., Marinescu, D., Emandi, A., Budrugeac, P., and Segal, E., J. Therm. Anal. Calor. 77, 815-824 (2004).

[5] Al-Asadi, R.H., Fahad, T. A. and Saeed, B.A. , J. of Advances in Chemistry , 9, 2078- 2091(2014)

[6] Li, X., Wu, Y., Gu, D. and Gan, F., 2010. Dyes Pigm., 86 ,182-189 (2010)

[7] Geng, Y., Gu, D., Gan, F., 2004. Application of novel azo metal thin film in optical recording. Opt. Mater., 27,193197(2004).

[8] N. Raman ${ }^{a^{*}}$, S. Johnson Raja ${ }^{a}$ \& A. Sakthivel ${ }^{2}$, J.of coordination chemistry, 92.(2009) 691-709

[9] Raman,N., Kulandaisamy, A., Shunmugasundaram, A. and Jeyasubramanian, K, Transition Metal Chemistry, 26 ,131135(2001)

[10] Professo, V. , Revbras otorrinolaringol,72, 400-460(2006).

[11] Ana,L. John, M. and John, F, Molecules , 13,519-547(2008)

[12] Famewo, C.E., Canad Anaesth. Soc. J., 28, (1981)

[13] Asaad, A.A. and Haider, J. of Basrah Researches ((Sciences)) 39, 76-88 ( 2013 )

[14] Asaad, A.A. and Haider, Basrah J. of Science, 32,(2014)

[15] Abboud,Y., Abourriche, A., Saffaj,T., Berrada, M., Charrouf, M., Bennamara, A., and Hannache, H., Desalination, 237, 175-189(2009)

[16] El-Ansary, AL., Issa, M.I. and Ali, A.A. , Indian J. of Chemistry , 23A., 933-936(1984)

[17] E.B.S \& Hiroshi ohoshiphotometric determination of traces of Metals fourth edition, 491, (1978).

[18] Makino, T., Clin.chim.Acta,197, 209(1991)

[19] Asaad A. A, Tark A. F. and Wesam A.A., J. of Kufa for Chemical Science, 8, 59-69(2013)

[20] Dean, J. A., "Lunges Handbook of Chemistry", Mcgrawhill, ING. New York, 15 Ed., 7. 55, (1999)

[21] Fahad T.A.. Ali A.A and Mohammed I.K., J. of Basrah Researches, 37,15-24(2011)

[22] M.K. Prasanna and K. Pradeep Kumar, Int J Pharm Biomed Sci 2013, 4(1), 24-29

[23] Harvey, D., Modern Analytical Chemistry, Mc Grow Hill, (2000)

[24] Hyde, A.G. and Dallas, N.B., Anal.chem.Acta., 24, 241 (1961).

[25] Irrving H. and Meller, D.P., J. Chem. Soc., 3957 (1955)

[26] Beck, M.T.," Chemistry of Complex equilibria ", Akademic kiado. Budapest )1970) 